\title{
Two New Chaetostoma Group (Loricariidae: Hypostominae) Sister Genera from Opposite Sides of the Andes Mountains in Ecuador, with the Description of One New Species
}

\author{
Nathan K. Lujan ${ }^{1,2,3}$, Vanessa Meza-Vargas ${ }^{4}$, and Ramiro Barriga-Salazar 5
}

\begin{abstract}
The new Chaetostoma-group genera Andeancistrus and Transancistrus are described based on recently collected material from rivers draining the respective Amazonian and Pacific slopes of the Andes Mountains in Ecuador. Andeancistrus is diagnosable from all other members of the Chaetostoma group by having a fully plated snout, lacking cheek odontodes that extend past the opercular flap, and by having eight vs. nine branched dorsal-fin rays. The new species Andeancistrus eschwartzae is also described and diagnosed from its only congener ( $A$. platycephalus) by having a black to dark gray base color of head and body (vs. light gray), irregularly shaped round to vermiculate yellow-gold spots smaller than half naris diameter evenly distributed across head, lateral and dorsal surfaces of the body and fin rays (vs. white to blue uniformly round spots), and by lacking enlarged clusters of odontodes at the posteromedial apex of most lateral body plates (vs. odontode clusters present). Transancistrus contains the species $T$. aequinoctialis and $T$. santarosensis, which can together be diagnosed from all other members of the Chaetostoma group except Chaetostoma by lacking plates along the anterior and lateral margins of the snout; they can be diagnosed from Chaetostoma by having a much narrower unplated snout region, approximately as wide as the maximum diameter of the orbit (vs. twice this width). Geographic distributions exclusive of drainages north of Ecuador and strong molecular phylogenetic evidence for a sister relationship between Andeancistrus and Transancistrus support the hypothesis that these genera may have once been contiguously distributed through a low-lying region of northern Peru and been separated via uplift of the Andes Mountains.
\end{abstract}

Se describen los nuevos géneros Andeancistrus y Transancistrus del grupo Chaetostoma basado en material recientemente colectado procedente de los ríos que drenan respectivamente las vertientes del Amazonas y del Pacífico de la Cordillera de los Andes en Ecuador. Andeancistrus es diagnosticado de todos los otros miembros del grupo Chaetostoma por tener un hocico totalmente cubierto de placas, ausencia de odontodes en las mejillas extendiendose posteriormente a la solapa opercular, y por tener ocho vs. nueve radios ramificados en la aleta dorsal. La nueva especie Andeancistrus eschwartzae también se describe y se diagnostica a partir de su único congénere ( $A$. platycephalus) por tener la cabeza y el cuerpo color negro a gris oscuro (vs. gris claro), puntos amarillo-oro con forma irregular redondeados a vermiculados más pequeños que la mitad del diámetro de la narina distribuidos uniformemente en la cabeza, las superficies laterales y dorsal del cuerpo y en los radios de las aletas (vs. puntos uniformemente redondos de color blanco a azul), y por carecer de grupos amplios de odontodes en el ápice posteromedial de la mayoría de las placas laterales del cuerpo (vs. grupos de odontodes presente). Transancistrus contiene las especies $T$. aequinoctialis y $T$. santarosensis las cuales se pueden diagnosticar de todos los otros miembros del grupo Chaetostoma excepto Chaetostoma por la ausencia de placas a lo largo de los márgenes anterior y lateral del hocico; pueden ser diagnosticados de Chaetostoma por tener una región muy reducida del hocico sin placas, aproximadamente tan ancha como el diámetro máximo de la órbita (vs. dos veces este ancho). Distribuciones geográficas exclusivas de las cuencas al norte de Ecuador y la fuerte evidencia filogenética molecular de la relación entre los grupos hermanos Andeancistrus y Transancistrus apoyan la hipótesis de que estos géneros podrían haber estado distribuidos de forma contigua a través de una región de tierras bajas del norte de Perú y se separaron posteriormente a través de la elevación de la Cordillera de los Andes.

\section{$\mathrm{T}$} HE genus Cordylancistrus was erected by Isbrücker (1980) for the species Pseudancistrus torbesensis Schultz, 1944. Since its erection, three new species of Cordylancistrus have been described (Co. perijae Pérez and Provenzano, 1996; Co. nephelion Provenzano and Milani, 2006; and Co. santarosensis Tan and Armbruster, 2012), and two species have been transferred into the genus: Burgess and Finley (1996) transferred Chaetostomus platycephalus Boulenger, 1898, and Isbrücker (2001) transferred Hemiancistrus daguae Eigenmann, 1912.

To date, there has been no comprehensive examination of relationships between all five species of Cordylancistrus; however, every phylogenetic study that has examined more than a single species has found them to be paraphyletic with respect to other closely related genera (i.e., Dolichancistrus, Leptoancistrus). These include two studies based on morphological data (Armbruster, 2008; Salcedo, 2013) and two studies based on molecular data (Lujan et al., 2015, in press). The most comprehensive of these is that by Lujan et al. (in press), which examines relationships between four valid species (Co. aequinoctialis, Co. torbesensis, Co. platycephalus, and Co. santarosensis), and one species described herein as new. They found Co. torbesensis to be sister to Dolichancistrus and part of a clade with Leptoancistrus that was sister to all four other putative congeners.

\footnotetext{
${ }^{1}$ Center for Systematic Biology and Evolution, Academy of Natural Sciences of Drexel University, 1900 Benjamin Franklin Parkway, Philadelphia, Pennsylvania 19103.

${ }^{2}$ Department of Natural History, Royal Ontario Museum, 100 Queen's Park, Toronto, Ontario, Canada M5S 2C6; E-mail: nklujan@gmail.com. Send reprint requests to this address.

${ }^{3}$ Department of Ecology and Evolutionary Biology, University of Toronto, Toronto, Ontario, Canada M5S 3B2.

${ }^{4}$ Departamento de Vertebrados, Museu Nacional, Quinta da Boa Vista, 20940-040 Rio de Janeiro, RJ, Brazil; E-mail: meza.sv@gmail.com.

${ }^{5}$ Instituto de Ciencias Biologas, Escuela Politécnica Nacional, Quito, Ecuador; E-mail: ramiro.barriga@epn.edu.ec.

Submitted: 4 February 2015. Accepted: 7 May 2015. Associate Editor: R. E. Reis.

(C) 2015 by the American Society of Ichthyologists and Herpetologists DOI: 10.1643/CI-15-246 Published online: September 18, 2015
} 
In this study, we describe two new genera for species previously considered part of Cordylancistrus, describe one new species from Ecuador, and redescribe Chaetostomus platycephalus Boulenger, 1898, based on freshly collected material.

\section{MATERIALS AND METHODS}

Morphometrics and meristics.-Morphometric and meristic data are presented in tables. Measurement landmarks follow Armbruster (2003); lateral trunk plate row terminology follows Schaefer (1997). Standard length (SL) is expressed in $\mathrm{mm}$ and other measurements are expressed as percentages of either standard length or head length. Measurements and counts were taken on the left side of specimens when possible. Institutional abbreviations follow Sabaj Pérez (2014).

\section{Andeancistrus, new genus}

urn:Isid:zoobank.org:act:B972E7D4-BFC3-40D2-806D-7F25BEF 502B5

Type species.-Chaetostomus platycephalus Boulenger, 1898.

Included taxa.-Andeancistrus eschwartzae, new species; Andeancistrus platycephalus (Boulenger, 1898), new combination.

Diagnosis.-Andeancistrus can be diagnosed from Transancistrus and all species of Chaetostoma except Chaetostoma platyrhyncha by having a fully plated snout, and from Cordylancistrus (Fig. 1), Dolichancistrus, and Leptoancistrus by lacking cheek odontodes that extend past the opercular flap. Andeancistrus can by diagnosed from Chaetostoma platyrhyncha by having distally hooked cheek odontodes (vs. straight), a larger adult body size (120-140 mm SL vs. $<80 \mathrm{~mm} \mathrm{SL}$ ), eight branched dorsal-fin rays (vs. typically 9), and by lacking a black spot at the anteroventral corner of the dorsal fin between the dorsal-fin spine and the first branched dorsal-fin ray (vs. spot present).

Sexual dimorphism.-Andeancistrus shares with many other members of the Chaetostoma group the hypertrophy of a fleshy ridge that runs along the posterodorsal margin of the unbranched pelvic-fin ray of sexually mature males (Fig. 2).

Distribution.-At present, the geographic range of described species of Andeancistrus is restricted to rivers draining the Amazonian slopes of the Andes Mountains in Ecuador south of the Napo River drainage, between approximately 330 and 1120 meters above sea level (m a.s.l.; Fig. 3); however, photographs of one or more undescribed species from tributaries of the Marañon River in northern Peru that likely also belong to this genus have been examined (NKL, pers. obs.). Extensive surveys by the first author of the Napo River drainage at these same elevations have revealed no similar species, suggesting that the range of this genus likely does not extend further to the north.

Etymology.-Andeancistrus is a combination of "Andean," a reference to the mountains from which this genus originates, and "ancistrus," a root name for many Hypostominae genera that have clusters of enlarged evertible cheek odontodes.
Andeancistrus eschwartzae, new species

urn:Isid:zoobank.org:act:2A1D96FB-202F-494D-944E-EB81F1 F31AA0

Figure 4; Tables 1, 2

Holotype.-MEPN 14780 (ex. ROM 93927), 143.5 mm SL, Ecuador, Morona-Santiago Province, Palora Canton, Sangay Sector, Pastaza River drainage, Amundalo River $10.3 \mathrm{~km}$ WSW of Palora, $01^{\circ} 44^{\prime} 54.90^{\prime \prime} \mathrm{S}, 78^{\circ} 02^{\prime} 39.78^{\prime \prime} \mathrm{W}, 953 \mathrm{~m}$ a.s.l., D. C. Taphorn, R. Barriga, A. Jackson, V. Román, 8 September 2012.

Paratypes.-All collected with holotype: ANSP 182818, 6, 51.2-115.2 mm SL; AUM 64664, 6, 52.9-117.2 mm SL; ROM 93927, 7, 26.2-125.9 mm SL.

Diagnosis.-Andeancistrus eschwartzae can be diagnosed from its only congener, A. platycephalus, by having black to dark gray base color of head and body (Fig. 4; vs. light gray, Fig. 2), irregularly shaped round to vermiculate yellow-gold spots smaller than half naris diameter evenly distributed across head, lateral and dorsal surfaces of body and fin rays (Fig. 4; vs. white to blue uniformly round spots, Fig. 2), and by lacking enlarged clusters of odontodes (keels) at posteromedial apex of most lateral body plates (Fig. 4; vs. odontode clusters present, Fig. 2).

Description.-Morphometrics in Table 1 and meristics in Table 2. Largest specimen $143.5 \mathrm{~mm}$ SL. Body depth increasing from tip of snout to greatest body depth at predorsal plates, decreasing to dorsalmost insertion of caudal fin. Dorsal profile convexly rounded between snout and supraoccipital, with very subtle hump at predorsal plates of adults. Ventral profile flat from snout to base of caudal fin. Ossified dermal plates with small odontodes covering head, body flanks, and ventral surface of tail posterior of anal-fin origin. Plates absent from abdomen. Cheek plates having nine to 38 enlarged, distally slightly hooked cheek odontodes (mode 14), longest odontodes never extending past opercular flap. Orbit positioned dorsally on head at approximately $45^{\circ}$ from sagittal plane in anterior view. Snout broadly rounded in dorsal view.

Oral disk occupying majority of ventral surface of head anterior of cleithrum. Teeth minute, bicuspid, with cusps bent $90^{\circ}$ toward mouth opening. Single digitate papilla extending ventrally from dorsal part of premaxillary symphysis; single cluster of low papillae at middle of interior surface of each mandible. Maxillary barbel short, attached to lower lip along most of length; ventral surface of labial disk with low hemispherical papillae decreasing in size distally.

Dorsal-fin spinelet small, inconspicuous, often covered with skin; posteriormost dorsal-fin ray free from body; reaching to within two or three plate rows of adipose-fin spine when adpressed. Pectoral fin reaching just beyond pelvic-fin base when adpressed, spine having enlarged odontodes along posterodorsal and distal surfaces. Pelvicfin spine not reaching anal-fin origin when adpressed. Adipose-fin spine straight or slightly curved, adnate to caudal peduncle via fleshy membrane. Caudal-fin margin straight, oblique, with ventral caudal-fin spine extending beyond dorsal caudal-fin spine.

Body broadest at cleithrum; posterior margin of exposed process of cleithrum rounded. First one to three midventral plates gently bent forming rounded ridge between verticals through pectoral- and dorsal-fin origins. 


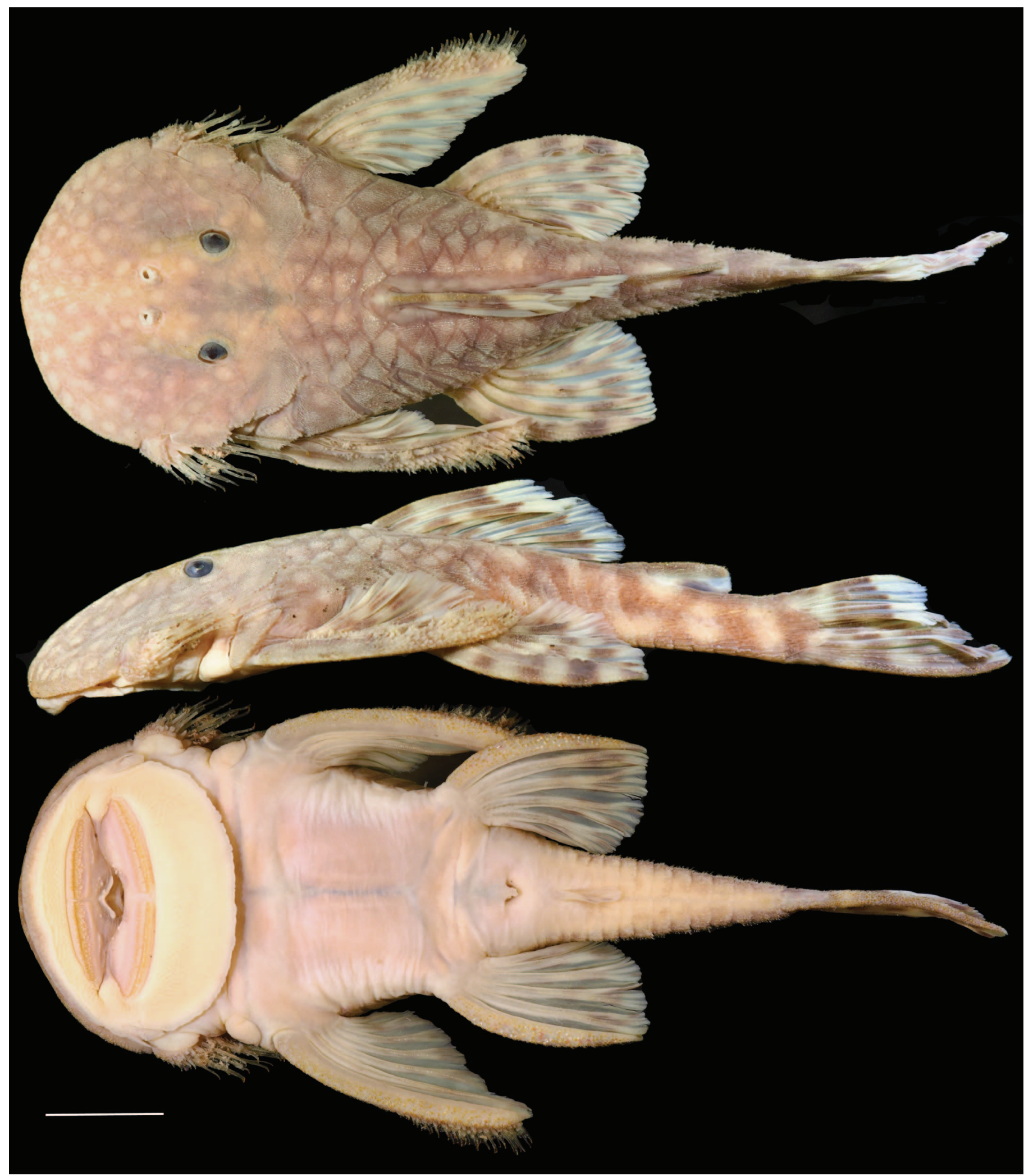

Fig. 1. Cordylancistrus torbesensis, AUM 22192, $64.6 \mathrm{~mm} \mathrm{SL}$, Venezuela, Táchira State, Torbes River drainage. Scale bar $=1 \mathrm{~cm}$. Photos by NKL.

Coloration in life.-Black to dark gray base color with irregularly shaped round to vermiculate yellow-gold spots smaller than half naris diameter evenly distributed across head, lateral and dorsal surfaces of body, and fin rays (Fig. 4). Abdomen light gray to white, ventral surface of body posterior of anus uniformly black to dark gray, generally lacking spots. Posterior margins of dorsal, pelvic, and caudal fins with light yellow to white bands as wide as naris.

Coloration in preservative.-Uniformly dark gray to black body and fins, abdomen light gray to white. Spots apparent only on fins. 


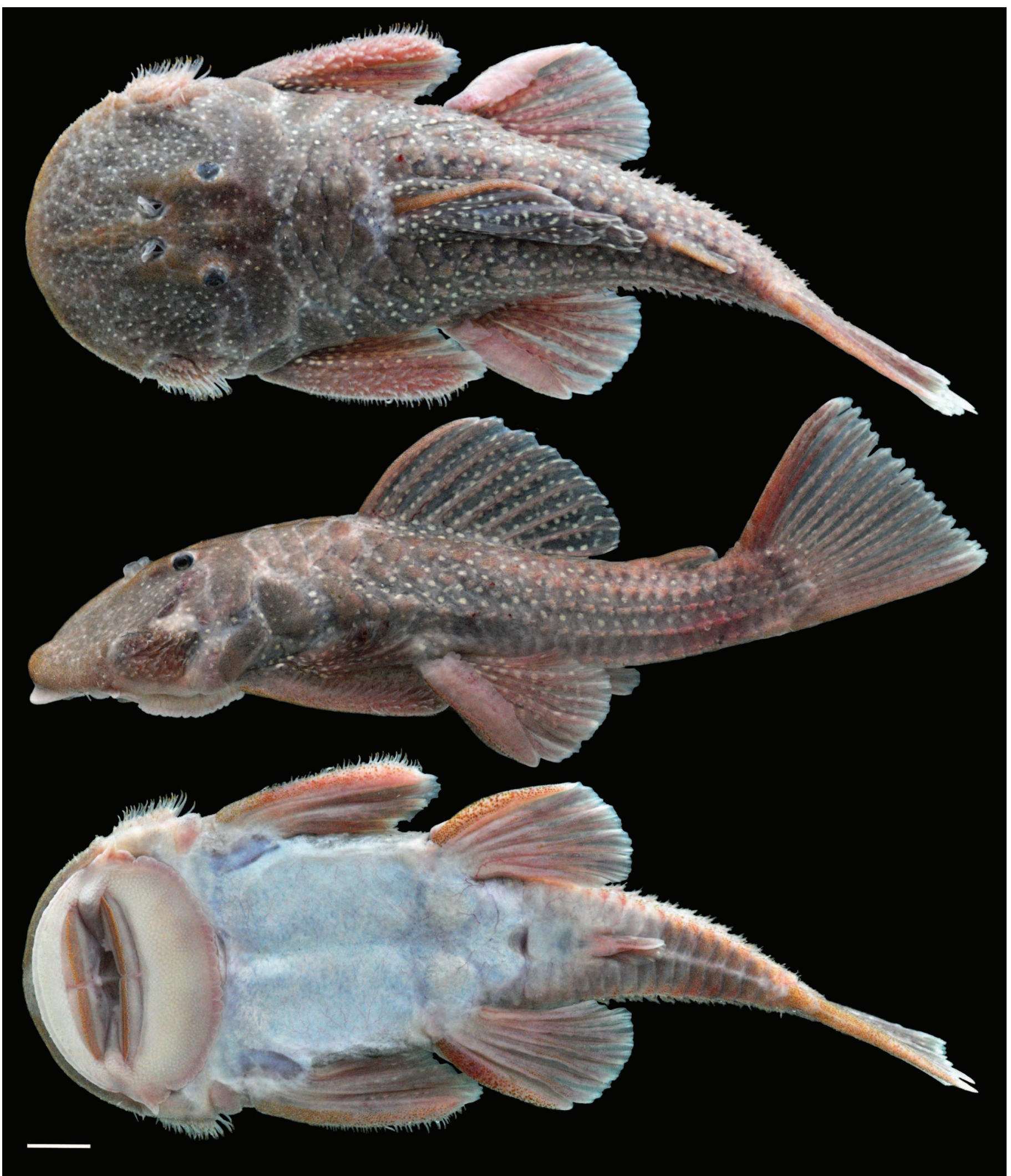

Fig. 2. Andeancistrus platycephalus, adult male, ROM 93880, $121.4 \mathrm{~mm} \mathrm{SL}$, Ecuador, Santiago River drainage (near type locality). Scale bar $=1 \mathrm{~cm}$. Photos by NKL.

Distribution.-Known only from a single locality at $953 \mathrm{~m}$ a.s.l. in the Amundalo River, a tributary of the Pastaza River in Morona-Santiago Province, Ecuador (Fig. 3). Likely widespread in the upper Pastaza River at similar elevations.
Etymology.-The species epithet eschwartzae honors Ms. Eugenia Schwartz, an artist and benefactor whose generous support through the Coypu Foundation made this research possible. 


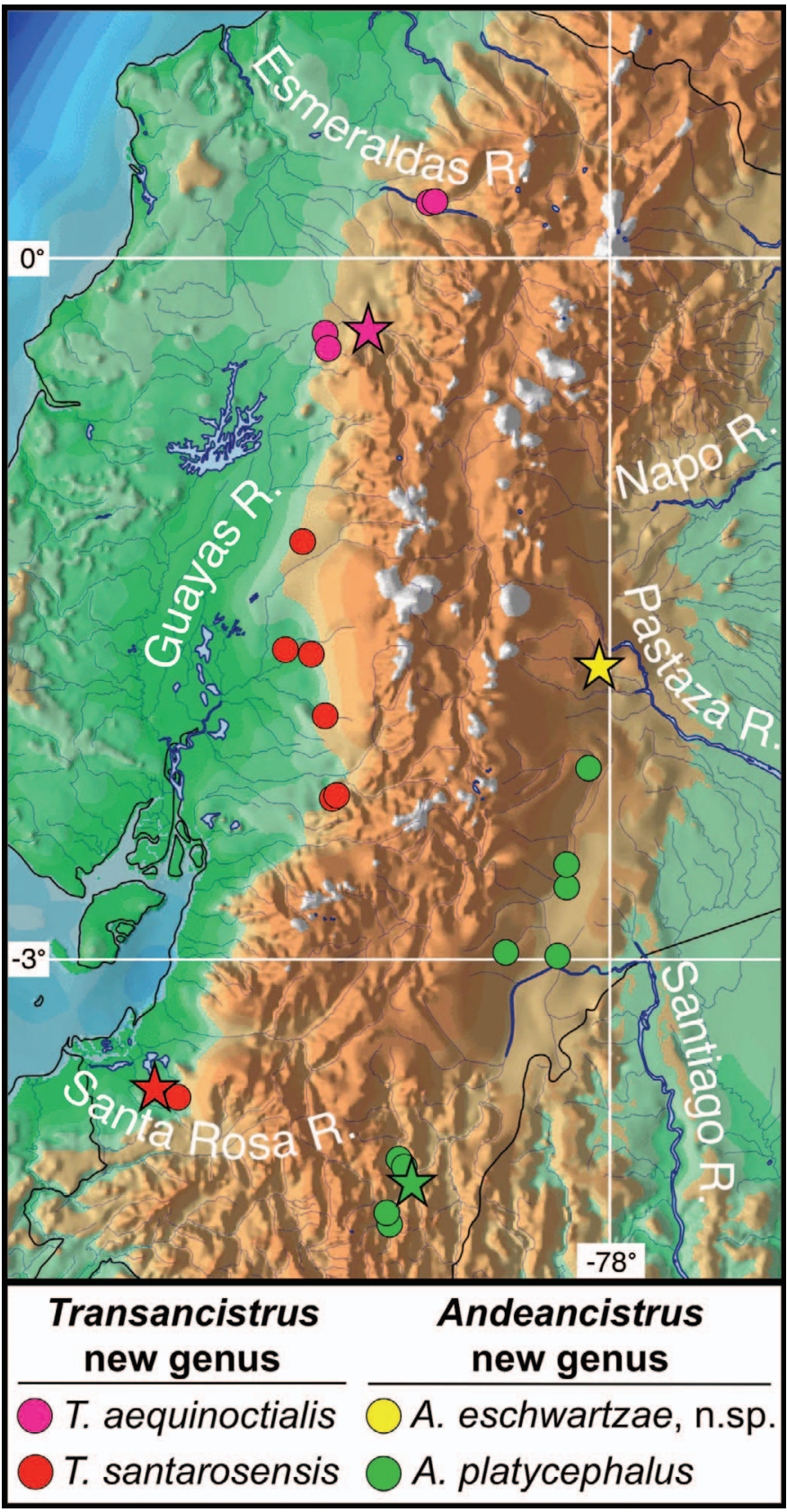

Fig. 3. Geographic distributions of specimens of Andeancistrus and Transancistrus examined in this study. Star = type locality. Left margin of map at $81.0^{\circ} \mathrm{W}$.

\section{Andeancistrus platycephalus (Boulenger, 1898)}

Figures 2, 5; Tables 1, 2

Syntypes.-BMNH 1898.11.4.42, 1, Ecuador, Santiago River drainage, Zamora-Chinchipe Province, Bomboiza River; MZUT 1551, 1, same data as BMNH 1898.11.4.42.

Non-type material.-Ecuador, Santiago River drainage, Zamora-Chinchipe Province, Zamora Canton: ROM 93847, 6, 42.7-91.8 mm SL, Bomboscara River $2.4 \mathrm{~km}$ SE of Zamora, downstream of Podocarpus National Park, $04^{\circ} 05^{\prime} 10.08^{\prime \prime}$, 78 57'19.50”W; ROM 93852, 6, 49.7-84.3 mm SL, Jambue River at cattle crossing $8.25 \mathrm{~km}$ SSE of Zamora, $04^{\circ} 08^{\prime} 15.42^{\prime \prime} \mathrm{S}, 78^{\circ} 56^{\prime} 29.34^{\prime \prime} \mathrm{W}$; ROM 93859, 1, $82.1 \mathrm{~mm}$ SL, Yacuambi River at community of Piunza, upstream of mouth of Piunza River, 03 $52^{\prime} 43.08^{\prime \prime} \mathrm{S}, 7^{\circ} 53^{\prime} 08.34^{\prime \prime} \mathrm{W}$; ROM 93862, 2, 72.5-91.0 $\mathrm{mm} \mathrm{SL}$, confluence of the Jambue and Zamora rivers, $03^{\circ} 57^{\prime} 37.30^{\prime \prime} \mathrm{S}, 7^{\circ} 50^{\prime} 49.18^{\prime \prime} \mathrm{W}$; ROM 93864, 1, $58.8 \mathrm{~mm}$ SL, Canzama River $24.4 \mathrm{~km}$ NNE of Zamora; right (W) bank tributary of Yacuambe River, 03 ${ }^{\circ} 51^{\prime} 25.80^{\prime \prime} \mathrm{S}$, $78^{\circ} 54^{\prime} 09.18^{\prime \prime} \mathrm{W}$. Morona-Santiago Province: ROM 93880, 6, 82.8-121.3 mm SL, Morona Canton, Yungantza River downstream of bridge $S$ of the town of Limón, $02^{\circ} 58^{\prime} 16.26^{\prime \prime} \mathrm{S}, 78^{\circ} 26^{\prime} 29.88^{\prime \prime} \mathrm{W}$; ROM 93883, 1, $45.9 \mathrm{~mm}$ SL, Morona Canton, Yunquiantza River at bridge crossing on road between Santiago and Mendez just upstream of confluence with Santiago River, 02 $58^{\prime} 56.16^{\prime \prime} \mathrm{S}$, $78^{\circ} 13^{\prime} 36.12^{\prime \prime} \mathrm{W}$; ROM 93890, 1, 51.3 mm SL, Sucúa Canton, confluence of the Changachangasa and Tutanangosa rivers and upstream in both, $02^{\circ} 35^{\prime} 51.18^{\prime \prime} \mathrm{S}, 78^{\circ} 11^{\prime} 10.38^{\prime \prime} \mathrm{W}$; ROM 93901, 2, 63.7-78.7 mm SL, Santiago Canton, Yumbiza River at bridge crossing $42.4 \mathrm{~km} \mathrm{~S}$ of Macas on Shuar reservation, $02^{\circ} 41^{\prime} 33.48^{\prime \prime}$ S, 78 $11^{\prime} 07.20^{\prime \prime} \mathrm{W}$; ROM 93907, 4, 57.6-114.3 mm SL, Morona Canton, Domono River at dirt road fork $15 \mathrm{~km} \mathrm{~N}$ of Macas, $02^{\circ} 10^{\prime} 56.82^{\prime \prime} \mathrm{S}, 78^{\circ} 05^{\prime} 41.34^{\prime \prime} \mathrm{W}$.

Diagnosis.-See diagnosis for the only congener A. eschwartzae above.

Description.-Morphometrics in Table 1 and meristics in Table 2. Largest specimen $122.1 \mathrm{~mm}$ SL. Body depth increasing from tip of snout to greatest body depth at predorsal plates, decreasing to dorsalmost insertion of caudal fin. Dorsal profile convexly rounded between snout and supraoccipital, with very subtle hump at predorsal plates of adults. Ventral profile flat from snout to base of caudal fin. Ossified dermal plates with small odontodes covering head, dorsum anterior of dorsal fin, and tail posterior of anal-fin origin; plates covering body flanks with enlarged keel-like clusters of odontodes at center of each plate with remainder of each plate covered in flesh. Plates absent from abdomen. Cheek plates having 11 to 38 enlarged, distally slightly hooked cheek odontodes (mode 14), longest odontodes never extending past the opercular flap. Orbit positioned dorsally on head at approximately $45^{\circ}$ from sagittal plane in anterior view. Snout broadly rounded in dorsal view.

Oral disk occupying majority of ventral surface of head anterior of cleithrum. Teeth minute, bicuspid, with cusps bent $90^{\circ}$ toward mouth opening. Single digitate papilla extending ventrally from dorsal part of premaxillary symphysis; single cluster of low papillae at middle of interior surface of each mandible. Maxillary barbel short, attached to lower lip along most of length; ventral surface of labial disk with low hemispherical papillae decreasing in size distally.

Dorsal-fin spinelet small, inconspicuous, often covered with flesh; posteriormost dorsal-fin ray free from body; reaches to within one or two plate rows of adipose-fin spine when adpressed. Pectoral fin reaching just beyond pelvic-fin base when adpressed, spine having enlarged odontodes along posterodorsal and distal surfaces. Pelvic-fin spine just reaching anal-fin origin when adpressed. Adipose-fin spine straight or slightly curved, adnate to caudal peduncle via fleshy membrane. Caudal-fin margin straight or weakly emarginate, oblique, with ventral caudal-fin spine extending beyond dorsal caudal-fin spine.

Body broadest at cleithrum; posterior margin of exposed process of cleithrum oblique. First one to three midventral plates gently bent forming rounded ridge between verticals through pectoral- and dorsal-fin origins. 


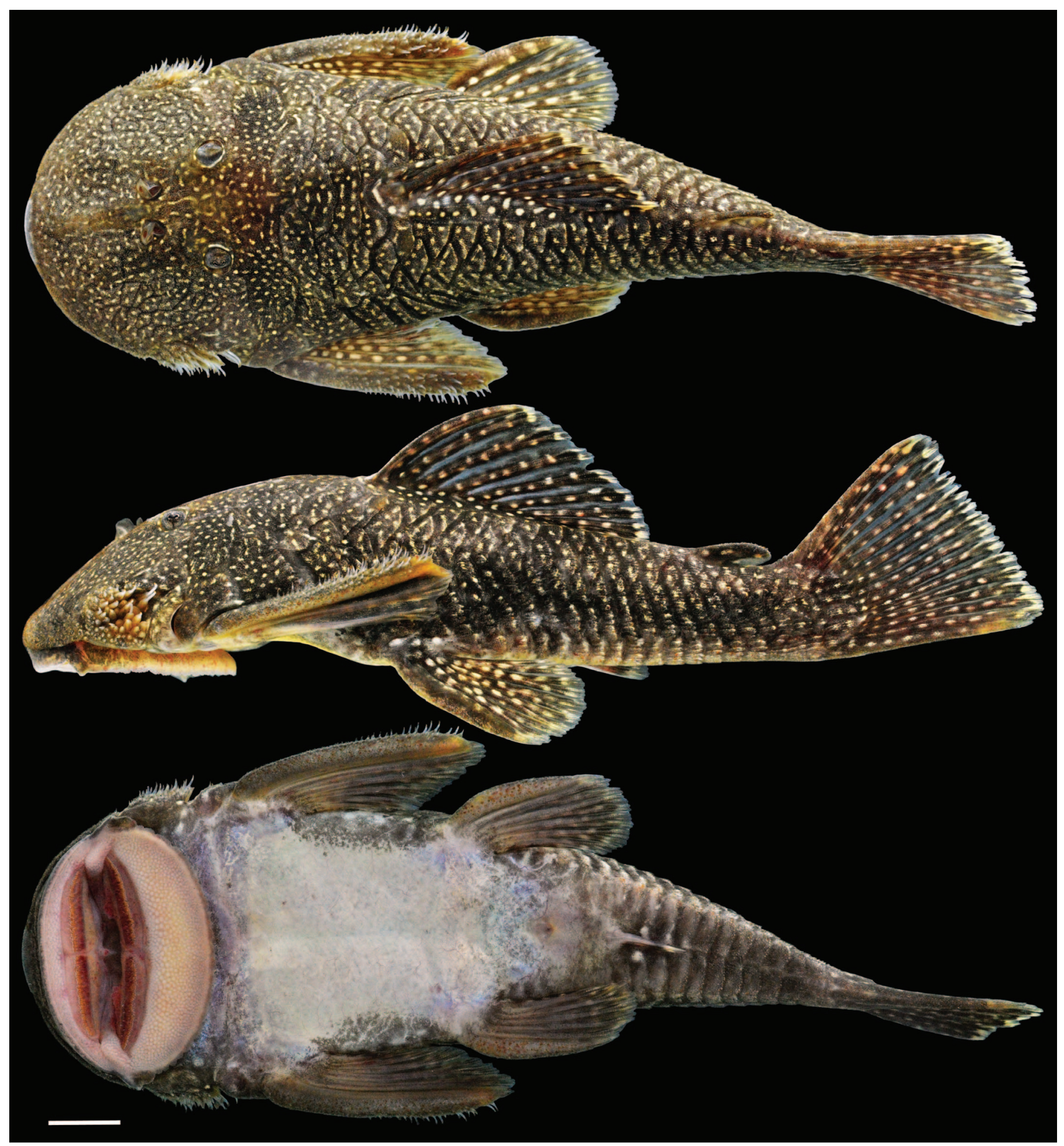

Fig. 4. Paratype of Andeancistrus eschwartzae, new species, AUM 64664, $107.8 \mathrm{~mm} \mathrm{SL}$, Ecuador, Pastaza River drainage. Scale bar $=1 \mathrm{~cm}$. Photos by NKL.

Coloration in life.-Light gray base color with uniformly shaped round white to light blue spots smaller than half naris diameter evenly distributed across head, lateral and dorsal surfaces of body and fin rays and membranes (Fig. 2, juveniles with relatively larger spots, Fig. 5). Abdomen white, ventral surface of body posterior of anus uniformly light gray, generally lacking spots. Posterior margins of dorsal, pelvic, and caudal fins with light white to yellow bands.
Coloration in preservative.-Uniformly dark gray body and fins, abdomen light gray to white. Spots apparent only on fins.

Distribution.-Widespread throughout the upper Santiago River drainage (Zamora-Chinchipe and Morona-Santiago provinces) at elevations from approximately 330 to 1120 meters above sea level (Fig. 3), although more common and abundant at the upper end of this range. 
Table 1. Selected morphometric characters and tooth counts for Andeancistrus eschwartzae, new species $(n=10)$, and $A$. platycephalus (Boulenger, 1898; $n=10$ ). Interlandmarks (ILM) are the two points between which measurements were taken (from Armbruster, 2003). Morphometric characters other than standard length presented as percents of either standard length or head length. Abbreviations: Min $=$ minimum value, Max $=$ maximum value, StDev $=$ standard deviation.

\begin{tabular}{|c|c|c|c|c|c|c|c|c|c|c|}
\hline \multirow[b]{2}{*}{ ILM } & \multirow[b]{2}{*}{ Measurement } & \multicolumn{5}{|c|}{$\begin{array}{c}\text { Andeancistrus eschwartzae, } \\
\text { new species }\end{array}$} & \multicolumn{4}{|c|}{$\begin{array}{l}\text { Andeancistrus platycephalus } \\
\text { (Boulenger, 1898) }\end{array}$} \\
\hline & & Holotype & Mean & StDev & Min & Max & Mean & StDev & Min & Max \\
\hline $1-20$ & Standard length (mm) & 143.5 & & & 64.1 & 143.5 & & & 78.2 & 122.1 \\
\hline \multicolumn{11}{|c|}{ Percents of standard length } \\
\hline $1-10$ & Predorsal length & 46.3 & 47.1 & 1.0 & 44.8 & 48.0 & 47.2 & 2.4 & 43.5 & 50.2 \\
\hline $1-7$ & Head length & 35.3 & 36.9 & 1.5 & 34.7 & 39.2 & 37.5 & 2.3 & 34.6 & 41.4 \\
\hline $7-10$ & Head-dorsal length & 11.0 & 10.7 & 1.1 & 8.5 & 12.3 & 10.5 & 1.0 & 8.2 & 11.7 \\
\hline $8-9$ & Cleithral width & 41.0 & 39.4 & 1.4 & 37.3 & 41.4 & 38.2 & 1.9 & 34.6 & 40.7 \\
\hline $1-12$ & Head-pectoral length & 33.4 & 33.2 & 1.8 & 31.6 & 37.8 & 33.3 & 1.7 & 30.5 & 35.9 \\
\hline $12-13$ & Thorax length & 22.5 & 22.2 & 0.9 & 20.8 & 23.9 & 21.8 & 1.0 & 20.0 & 23.8 \\
\hline $12-29$ & Pectoral-spine length & 30.8 & 28.9 & 2.3 & 26.4 & 32.5 & 28.0 & 1.9 & 25.0 & 30.3 \\
\hline $13-14$ & Abdominal length & 32.4 & 23.9 & 3.2 & 20.7 & 32.4 & 22.3 & 0.8 & 21.3 & 24.2 \\
\hline $13-30$ & Pelvic-spine length & 19.5 & 20.9 & 0.9 & 19.5 & 22.2 & 22.6 & 1.5 & 20.8 & 25.3 \\
\hline $14-15$ & Postanal length & 28.8 & 30.2 & 1.2 & 28.8 & 32.7 & 30.3 & 1.0 & 29.0 & 32.2 \\
\hline $14-31$ & Anal-fin spine length & 10.8 & 8.9 & 1.3 & 7.3 & 10.9 & 9.9 & 1.3 & 8.2 & 11.7 \\
\hline $7-12$ & Head depth & 26.3 & 26.2 & 0.6 & 25.6 & 27.3 & 25.9 & 1.4 & 23.9 & 27.9 \\
\hline $10-12$ & Dorsal-pectoral depth & 29.7 & 30.5 & 0.6 & 29.5 & 31.2 & 30.0 & 1.3 & 28.4 & 31.4 \\
\hline $10-11$ & Dorsal spine length & 30.7 & 22.5 & 3.7 & 16.8 & 30.7 & 24.5 & 1.9 & 22.7 & 28.2 \\
\hline $10-13$ & Dorsal-pelvic depth & 24.8 & 24.2 & 1.2 & 22.5 & 25.8 & 24.3 & 1.9 & 21.9 & 28.7 \\
\hline $10-16$ & Dorsal-fin base length & 26.7 & 25.6 & 1.0 & 24.1 & 27.3 & 26.1 & 0.5 & 25.6 & 27.5 \\
\hline $16-17$ & Dorsal-adipose depth & 13.7 & 14.2 & 0.9 & 12.5 & 16.0 & 13.0 & 1.2 & 10.8 & 15.3 \\
\hline $17-18$ & Adipose-spine length & 8.8 & 9.2 & 0.6 & 8.1 & 10.4 & 8.9 & 0.6 & 8.0 & 9.7 \\
\hline $17-19$ & Adipose-upper caudal length & 15.1 & 16.3 & 1.3 & 14.6 & 18.4 & 16.9 & 1.3 & 15.0 & 19.7 \\
\hline $15-19$ & Caudal peduncle depth & 13.1 & 12.5 & 0.6 & 11.4 & 13.6 & 12.4 & 0.5 & 11.7 & 13.2 \\
\hline $15-17$ & Adipose-lower caudal depth & 21.8 & 22.4 & 0.8 & 20.9 & 23.3 & 22.2 & 1.4 & 20.7 & 25.6 \\
\hline $14-17$ & Adipose-anal depth & 18.7 & 19.7 & 0.6 & 18.7 & 20.5 & 18.9 & 0.7 & 17.9 & 19.9 \\
\hline $14-16$ & Dorsal-anal depth & 16.6 & 16.6 & 0.4 & 16.1 & 17.2 & 15.9 & 0.7 & 14.8 & 16.8 \\
\hline $13-16$ & Pelvic-dorsal depth & 26.6 & 27.1 & 1.0 & 25.1 & 28.8 & 26.6 & 1.1 & 24.8 & 28.0 \\
\hline \multicolumn{11}{|c|}{ Percents of head length } \\
\hline $5-7$ & Head-eye length & 28.7 & 29.3 & 0.7 & 28.5 & 30.5 & 28.9 & 0.9 & 27.3 & 30.2 \\
\hline $4-5$ & Orbit diameter & 8.2 & 10.1 & 1.0 & 8.2 & 12.0 & 9.9 & 0.9 & 8.6 & 11.5 \\
\hline $1-4$ & Snout length & 69.3 & 68.5 & 1.3 & 66.5 & 70.0 & 69.1 & 1.9 & 65.3 & 71.4 \\
\hline $2-3$ & Internares width & 11.5 & 9.0 & 1.4 & 7.3 & 11.5 & 9.0 & 0.5 & 8.2 & 9.5 \\
\hline $5-6$ & Interorbital width & 30.3 & 28.1 & 1.2 & 26.3 & 30.3 & 28.2 & 1.1 & 26.7 & 29.9 \\
\hline $1-24$ & Mouth length & 69.2 & 68.9 & 2.7 & 65.6 & 75.5 & 70.9 & 3.2 & 66.2 & 75.6 \\
\hline $21-22$ & Mouth width & 89.4 & 86.8 & 2.9 & 82.3 & 91.9 & 83.8 & 3.0 & 79.4 & 88.0 \\
\hline $22-23$ & Barbel length & 3.9 & 3.9 & 1.3 & 2.5 & 6.7 & 7.1 & 2.1 & 4.0 & 11.0 \\
\hline $25-26$ & Dentary tooth cup length & 35.2 & 34.2 & 1.1 & 31.5 & 35.4 & 33.0 & 2.1 & 31.0 & 37.5 \\
\hline $27-28$ & Premax. tooth cup length & 30.5 & 29.5 & 1.0 & 27.2 & 30.7 & 29.3 & 2.3 & 26.5 & 33.4 \\
\hline \multicolumn{11}{|c|}{ Tooth counts } \\
\hline & Left premaxillary teeth & 114 & 110 & 10 & 89 & 120 & 101 & 25 & 43 & 123 \\
\hline & Left dentary teeth & 177 & 146 & 19 & 109 & 177 & 140 & 38 & 51 & 183 \\
\hline
\end{tabular}

\section{Transancistrus, new genus}

urn:Isid:zoobank.org:act:D805637D-68C7-4A6A-A5C2-11B1FE 0303 C7

Type species.-Cordylancistrus santarosensis Tan and Armbruster, 2012.

Included taxa.-Transancistrus aequinoctialis (Pellegrin, 1909), new combination; Transancistrus santarosensis (Tan and Armbruster, 2012), new combination.

Diagnosis.-Transancistrus can be diagnosed from all other members of the Chaetostoma group except Chaetostoma by lacking plates along the anterior and lateral margins of the snout. Transancistrus can be diagnosed from Chaetostoma by having the unplated snout region much narrower, approximately as wide as the maximum diameter of the orbit (vs. twice this width; see Tan and Armbruster, 2012 and Lujan and Armbruster, 2011, for illustrations of patterns of snout plate loss that are characteristic of various loricariid genera).

Sexual dimorphism.-Transancistrus shares with Andeancistrus and many other members of the Chaetostoma group the hypertrophy of a fleshy ridge that runs along the posterodorsal margin of the unbranched pelvic-fin ray of sexually 
Table 2. Selected meristic characters for Andeancistrus eschwartzae, new species $(n=10)$, and $A$. platycephalus (Boulenger, 1898; $n=10)$. Abbreviations: Min = minimum value, Max = maximum value.

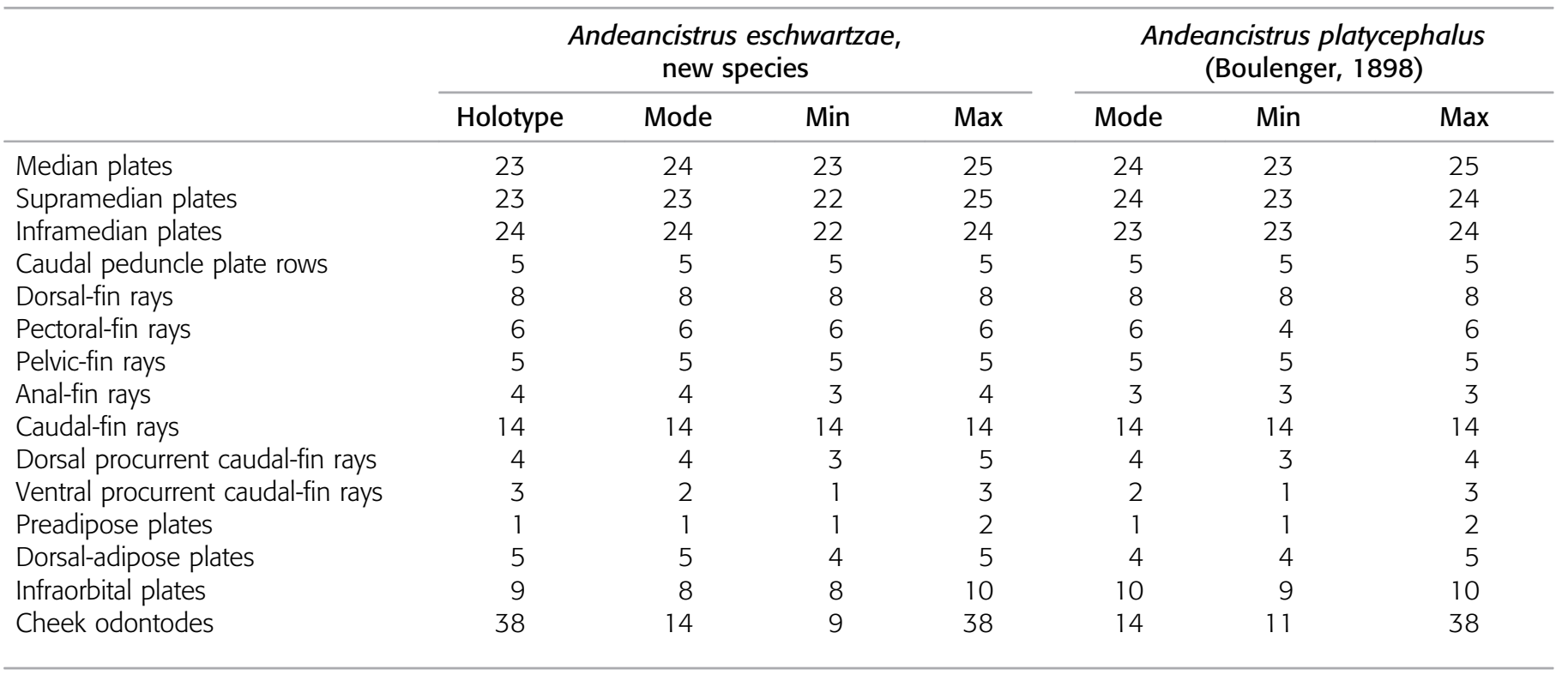

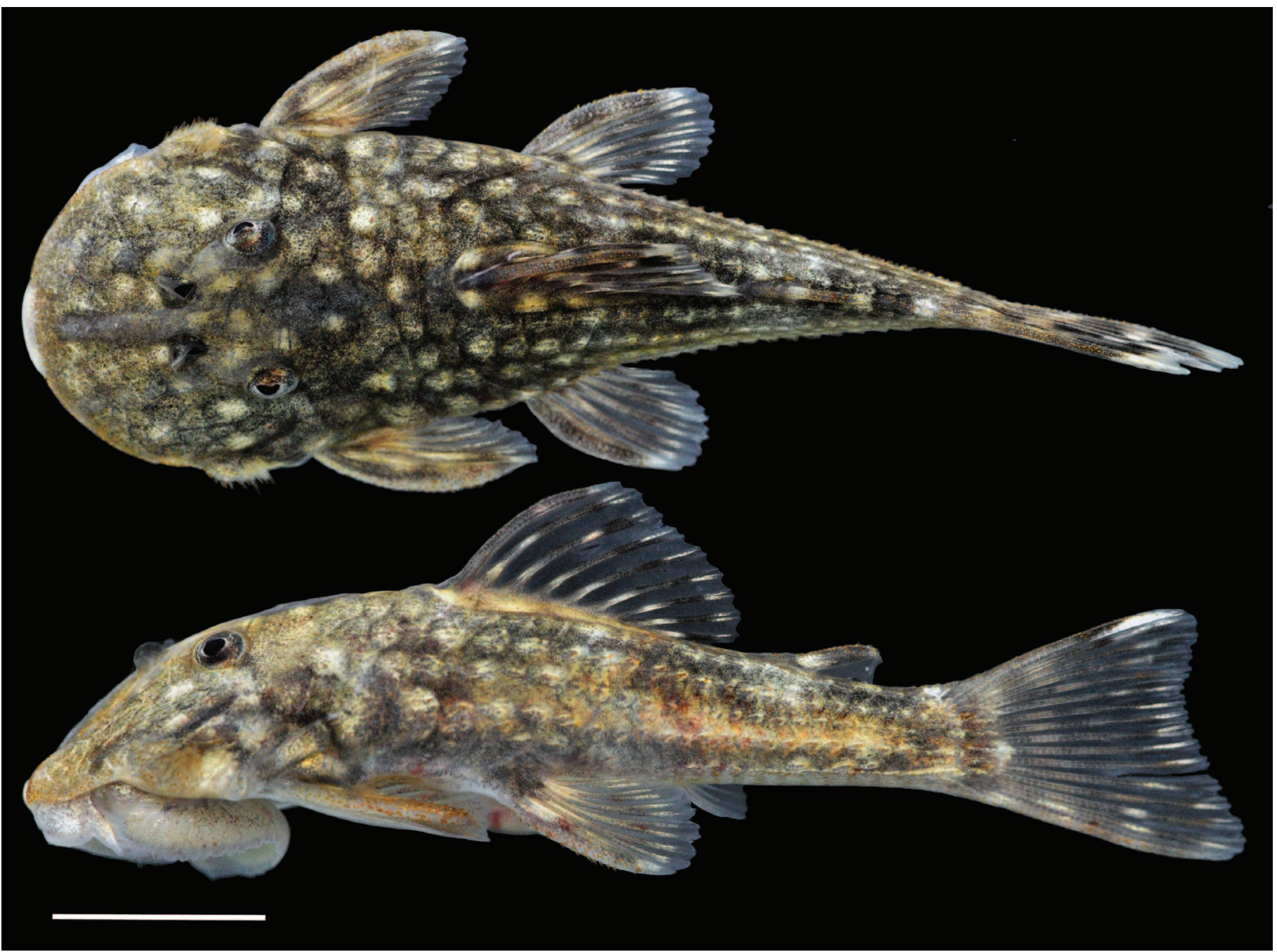

Fig. 5. Andeancistrus platycephalus, juvenile, ROM 93847, $41.9 \mathrm{~mm} \mathrm{SL}$, Ecuador, Santiago River drainage (near type locality). Scale bar $=1 \mathrm{~cm}$. Photos by NKL. 
mature males; however, this fleshy ridge is not as enlarged in Transancistrus (Fig. 6C) as in Andeancistrus (Fig. 2).

Distribution.-Transancistrus is known only from elevations between 54 and $696 \mathrm{~m}$ a.s.l. in rivers draining the Pacific slope of the Andes Mountains in Ecuador, between the Esmeraldas River drainage in the north and the Santa Rosa River drainage in the south (Fig. 3).

Etymology.-Transancistrus is a combination of the Latin word "trans," meaning "across, over, or on the other side of," which refers to the distribution of this genus across rivers draining the Pacific slope of the Andes Mountains in Ecuador, and "ancistrus," a root name for many Hypostominae genera having clusters of enlarged evertible cheek odontodes.

Remarks.-Transancistrus aequinoctialis (Fig. 6) was originally described as Chaetostomus aequinoctialis Pellegrin, 1909 based on specimens from the Pove River near Santo Domingo de los Colorados-a tributary of the Esmeraldas River that drains the northwest Pacific Coast of Ecuador. Transancistrus aequinoctialis has long been assumed to be a member of the genus Chaetostoma based largely on the absence of plates from the margin of the snout of the holotype (MNHN 1904-0017), and the well-known common occurrence of Chaetostoma in rivers along the entire Pacific Coast of Ecuador. Indeed, many specimens of Chaetostoma sensu stricto from throughout the Pacific Coast of Ecuador, in Ecuadorian museums and abroad, are identified as "Chaetostoma aequinoctiale." However, a closer examination of the holotype of Chaetostomus aequinoctialis Pellegrin, 1909 reveals a much narrower band of naked flesh around the snout, a more dorsoventrally depressed body, and a greater number of cheek odontodes than are observed in Chaetostoma sensu stricto from the Pacific of Ecuador.

Collections by us in August 2012 near Santo Domingo de los Colorados (Fig. 6), and in several other Pacific Coast drainages of Ecuador (Figs. 7, 8), yielded a species very similar to one previously known only from the Santa Rosa River in southwest Ecuador-one that was then recently described as Cordylancistrus santarosensisTan and Armbruster, 2012. Comparison of our fresh material from the Esmeraldas, Santa Rosa, and intervening river drainages (see Material Examined below, and Fig. 3), with the holotype of Chaetostomus aequinoctialis confirmed that they share the diagnostic characteristics of Transancistrus. Although Transancistrus is frequently sympatric with Chaetostoma, most life stages of the former can be easily distinguished from those of the latter based on overall head and body shape (Transancistrus being generally more dorsoventrally flattened with a relatively shorter body and wider head), cheek odontode number (Transancistrus having generally more than 12 cheek odontodes, vs. only two for the only Chaetostoma species that co-occurs in most Pacific Coast drainages of Ecuador, see Lujan et al., in press), and the narrowness of the naked snout margin (Transancistrus naked snout margin being as wide as the maximum diameter of the orbit, vs. twice this width for Chaetostoma).

Transancistrus remains in need of further study to resolve the validity and geographic boundaries of $T$. aequinoctialis (Fig. 6) from the Esmeraldas River drainage in northwestern Ecuador (Fig. 3), and T. santarosensis from the Santa Rosa River drainage in southwestern Ecuador (Fig. 3). Specimens assignable to Transancistrus from rivers throughout western Ecuador exhibit a gradient in coloration (Fig. 8) from patterns more typical of $T$. aequinoctialis in the north (i.e., large indistinct and irregular black spots on a light green to brown base color; Figs. 6, 8A) to patterns more typical of $T$. santarosensis in the south (i.e., spots generally fused into indistinct and irregular bands on a light to dark brown base color; Figs. 7, 8C). Given the subtlety of this color variation, the need to collect additional morphometric and meristic data from a large number of specimens, and the value of also incorporating population-level molecular genetic methods to more precisely delimit species, we defer a formal redescription of $T$. aequinoctialis and $T$. santarosensis until more data and specimens are available.

\section{DISCUSSION}

Andeancistrus and Transancistrus were found to be strongly supported as sister to each other (Bayesian posterior probability: 1.0, maximum likelihood bootstrap: 100) and respectively monophyletic (BI: 1.0, ML: 100) in the respective DNA-based phylogenetic analyses of Lujan et al. (2015, in press). The apparent absence of any members of these genera from drainages to the north of Ecuador suggests that they diverged vicariantly via uplift of the Andes Mountains, rather than via secondary dispersal around the coastal lowlands of northwestern South America. The lowest contemporary pass through the central Andes Mountains is the Porculla Pass (2137 m a.s.l.), approximately $80 \mathrm{~km}$ west of Jaen in northern Peru. Given the likely occurrence of other undescribed species of Andeancistrus in tributaries of the upper Marañon near Jaen in northern Peru (NKL, pers. obs.), it seems at least plausible that the Andeancistrus + Transancistrus clade may have once had a contiguous distribution through a portion of northern Peru that was much lower in elevation prior to the Late Miocene surge in Andean uplift (Gregory-Wodzicki, 2000).

Similar hypotheses of a historical "Marañon Portal" have been previously proposed (e.g., Brooks, 1992) but have to date received little support from biogeographical studies of freshwater biota (e.g., mollusks, Nuttall, 1990; potamotrygonid stringrays, Lovejoy, 1996). The strongest evidence in support of a historical low-lying area or gap in the Andes Mountains in northern Peru comes from biogeographical studies of a number of montane plant families (e.g., Campanulaceae, Calceolariaceae, Tropaeolaceae, Loasaceae, Passifloraceae, Alstroemeriaceae, and Grossulariaceae; Taylor, 1991; Antonelli et al., 2009). Andean members of these families display repeated patterns of endemism either to the north or the south of the low-lying Marañon region, which is often referred to in botanical literature as the Western Atlantic Portal. In the event that Andeancistrus and Transancistrus did diverge vicariantly as a result of Andean uplift in the Late Miocene, then this datable node provides an excellent internal point for time-calibrating the molecular phylogeny of the Loricariidae, a group that otherwise lacks early and informative internal fossil calibrations (Lujan et al., 2015).

With the removal of Andeancistrus platycephalus, Transancistrus aequinoctialis and T. santarosensis from Cordylancistrus, the latter genus is left with only four species: the type species Co. torbesensis plus Co. daguae, Co. nephelion, and Co. perijae. Despite the resolution herein of some of the previously demonstrated paraphyly within Cordylancistrus (Armbruster, 2004, 2008; Salcedo, 2013; Lujan et al., 2015, in press), the genus remains in need of further systematic revision. Based on their descriptions alone, it seems likely that none of the three non-type species of Cordylancistrus are more closely 


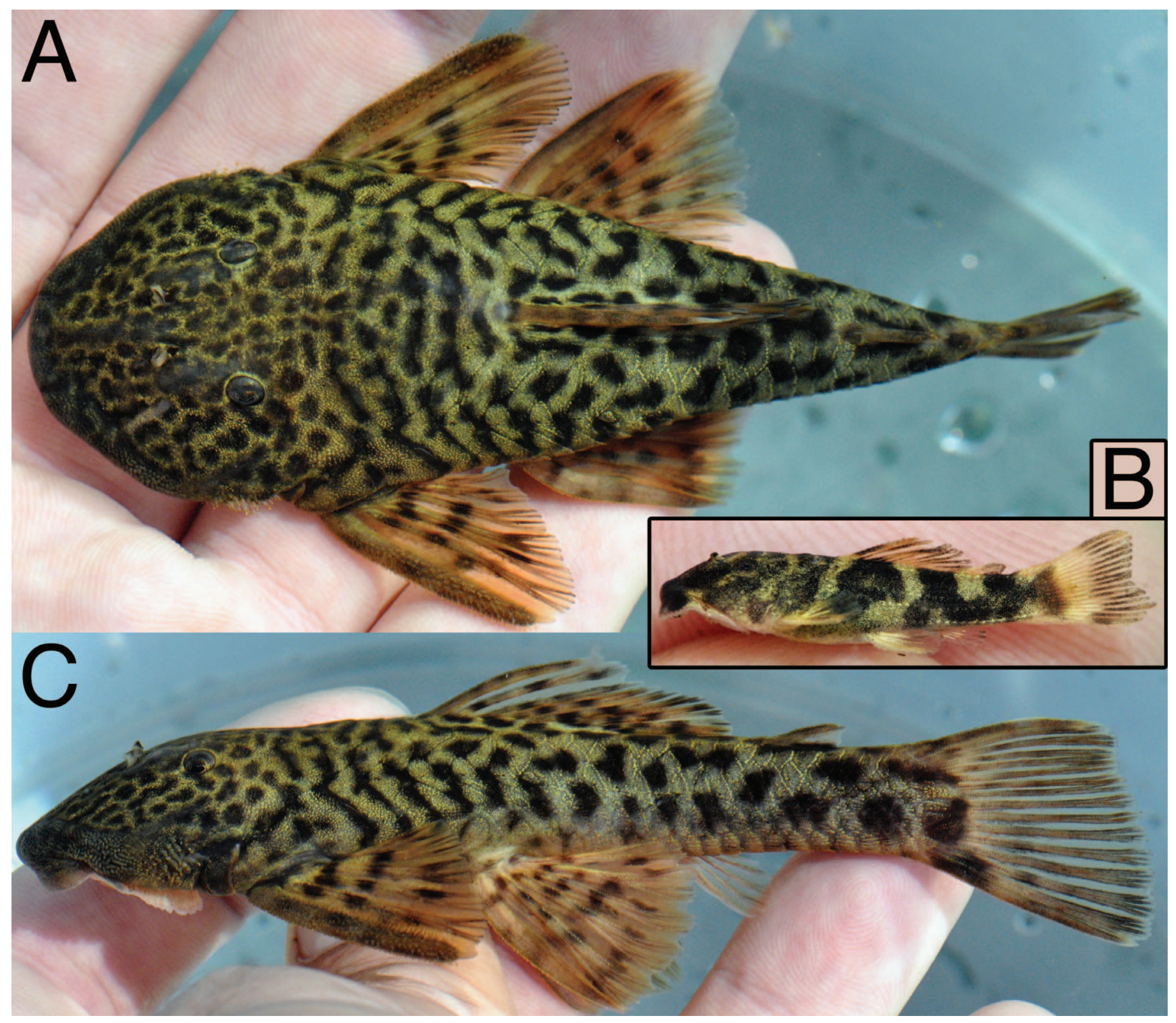

Fig. 6. Transancistrus aequinoctialis adult (A, C: ROM 93666, $85.2 \mathrm{~mm} \mathrm{SL})$ and juvenile (B: ROM 93695, $28.5 \mathrm{~mm} \mathrm{SL)} \mathrm{from} \mathrm{northern} \mathrm{(A,} \mathrm{C)} \mathrm{and}$ southern (B) tributaries of the Esmeraldas River drainage. Photos by NKL.

related to $C$. torbesensis than to other members of the Chaetostoma group. We believe that it is more appropriate to treat them as incertae sedis within the Chaetostoma group than as true Cordylancistrus, at least until such time as a systematic revision and phylogenetic analysis inclusive of those taxa can be performed. Unfortunately, specimens for all three remaining non-type species are scarce in collections and tissues for genetic analysis are unavailable.

\section{MATERIAL EXAMINED}

Cordylancistrus torbesensis: all Venezuela, Táchira State, Torbes River drainage: AUM 22192, 4, 23.2-64.6 mm SL, Quinimari River at Santa Ana, $07^{\circ} 39^{\prime} 54.0^{\prime \prime} \mathrm{N}, 72^{\circ} 15^{\prime} 04.0^{\prime \prime} \mathrm{W}$; MCZ 36170, 1 (via CT scan), 53 mm SL, Torbes River 1 km above Táriba.

Transancistrus aequinoctialis: all Ecuador, Esmeraldas River drainage (Pacific Coast), Pichincha Province: ROM 93661,
3, 48.9-72.8 mm SL, Quito Canton, confluence of the Chontal and Guallabamba rivers, $00^{\circ} 14^{\prime} 29.70^{\prime \prime} \mathrm{N}$, 78 45'16.56"W; ROM 93666, 6, 32.2-85.9 mm SL, Quito Canton, Magdalena River at Osho Resort (Ecolodge) and Guallabamba River at confluence with Magdalena, $00^{\circ} 14^{\prime} 32.10^{\prime \prime} \mathrm{N}, 78^{\circ} 46^{\prime} 21.24^{\prime \prime} \mathrm{W}$; ROM 93695, 6, 29.5-89.9 mm SL, Santo Domingo de los Colorados Canton, Leilia River upstream of Hwy 30 bridge, E of Santo Domingo de los Colorados, $00^{\circ} 18^{\prime} 48.60^{\prime \prime} \mathrm{S}, 7^{\circ} 02^{\prime} 03.78^{\prime \prime} \mathrm{W}$; ROM 93705, 1, 37.5 mm SL, Santo Domingo de los Colorados Canton, Chihuilpe River at bridge-crossing and downstream, $00^{\circ} 19^{\prime} 21.00^{\prime \prime} \mathrm{S}, 79^{\circ} 12^{\prime} 59.76^{\prime \prime} \mathrm{W}$.

Transancistrus cf. aequinoctialis: all Ecuador, Guayas River drainage (Pacific Coast), Pichincha Province: ROM 93711, 4, 44.7-81.0 mm SL, Santo Domingo de los Colorados Canton, Rio Otongo, Otongo R. at bridge crossing, $00^{\circ} 22^{\prime} 59.76^{\prime \prime} \mathrm{S}, 79^{\circ} 12^{\prime} 26.22^{\prime \prime} \mathrm{W}$. 


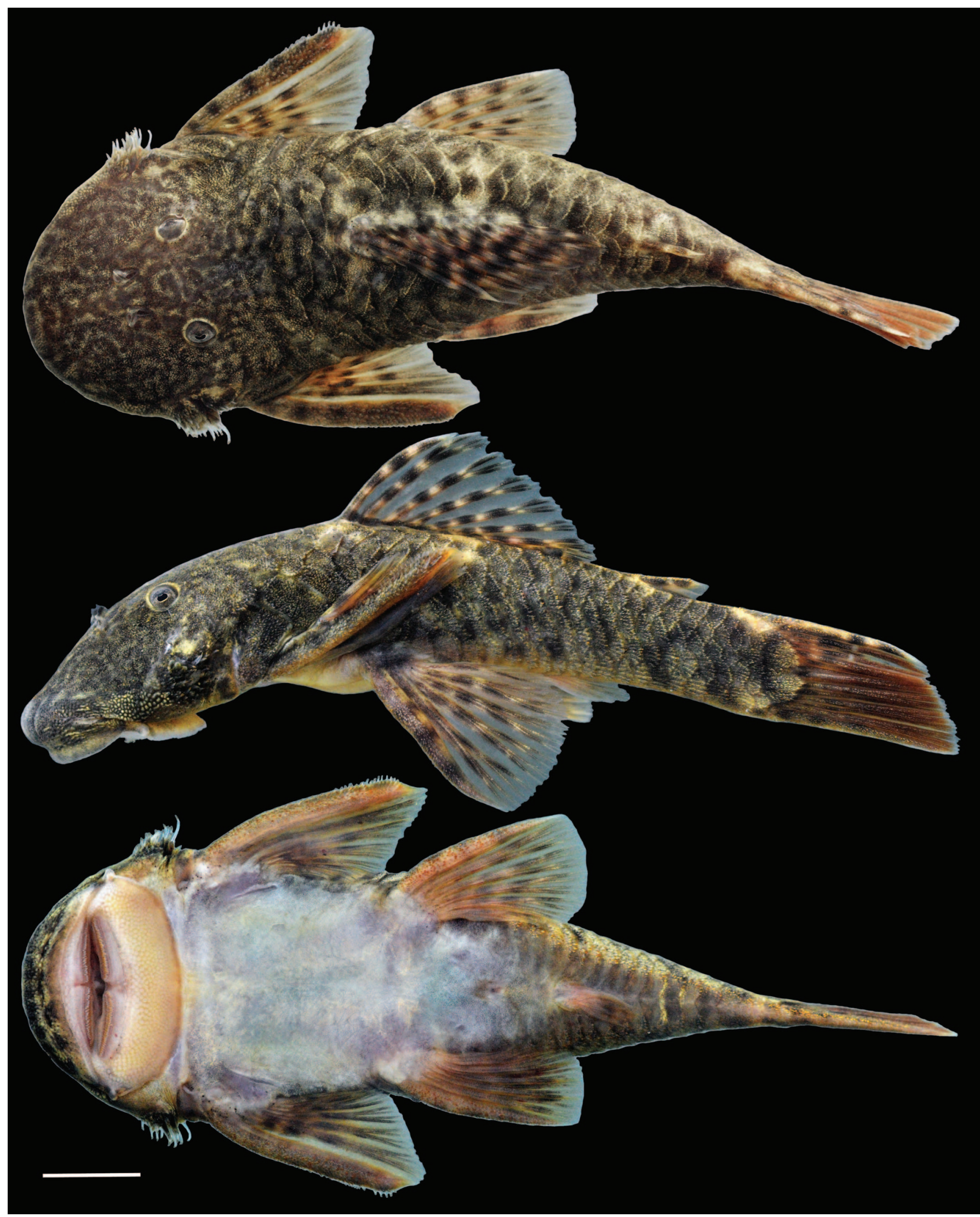

Fig. 7. Transancistrus santarosensis from the Santa Rosa River drainage (ROM 93798, $75.5 \mathrm{~mm} \mathrm{SL}$ ). Scale bar $=1 \mathrm{~cm}$. Photos by NKL. 


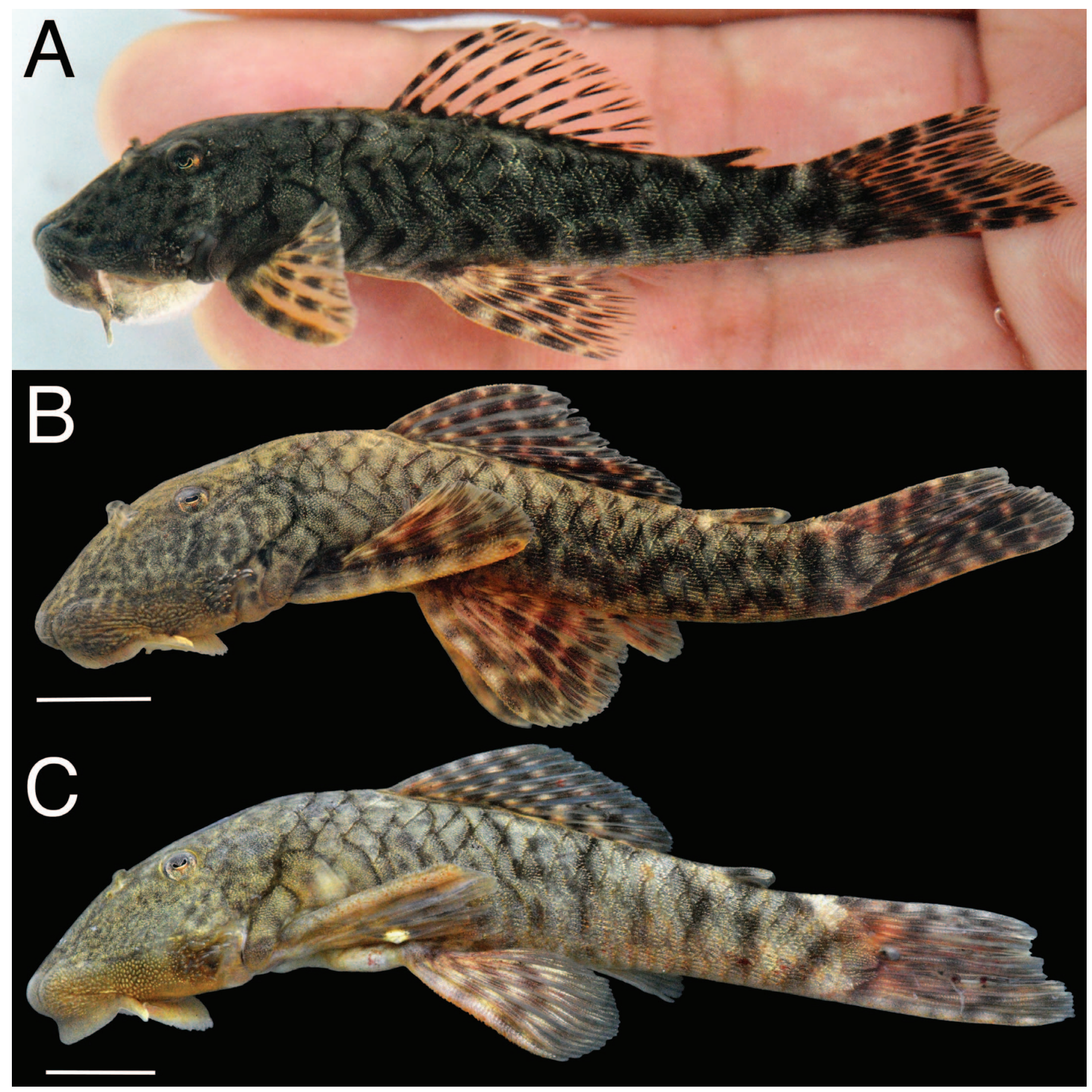

Fig. 8. Transancistrus cf. aequinoctialis from the northern Guayas River drainage (A: ROM 93711, $55.3 \mathrm{~mm} \mathrm{SL),} \mathrm{and} \mathrm{T.} \mathrm{cf.} \mathrm{santarosensis} \mathrm{from} \mathrm{the}$ central Guayas (B: ROM 93728, $75.5 \mathrm{~mm} \mathrm{SL}$ ), and Taura river drainages (C: ROM 93728, $75.8 \mathrm{~mm} \mathrm{SL}$ ). Scale bars $=1 \mathrm{~cm}$. Photos by NKL.

Transancistrus santarosensis: all Ecuador, Santa Rosa River drainage (Pacific Coast), El Oro Province, Santa Rosa Canton: ROM 93792, 1, $48.5 \mathrm{~mm} \mathrm{SL}$, Santa Rosa River at La Avanzada bathing area, $03^{\circ} 33^{\prime} 30.42^{\prime \prime} \mathrm{S}, 79^{\circ} 56^{\prime} 48.12^{\prime \prime} \mathrm{W}$; ROM 93798, 4, 63.4-76.8 mm SL, Santa Rosa River 20.8 km SE of town of Santa Rosa, $03^{\circ} 35^{\prime} 35.46^{\prime \prime} \mathrm{S}, 79^{\circ} 50^{\prime} 44.04^{\prime \prime} \mathrm{W}$.

Transancistrus cf. santarosensis: Guayas River drainage, Los Rios Province: ROM 93728, 4, 44.2-57.0 mm SL, Las Naves Canton, Umbe River at bridge crossing in Las Palmitas, $01^{\circ} 12^{\prime} 38.52^{\prime \prime} \mathrm{S}, 7^{\circ} 18^{\prime} 40.68^{\prime \prime} \mathrm{W}$; ROM 93732, 20, 16.1-83.1 mm SL, Montalvo Canton, La Esmeralda River at community of La Esmeralda, $01^{\circ} 41^{\prime} 57.48^{\prime \prime} \mathrm{S}, 7^{\circ} 16^{\prime} 26.10^{\prime \prime} \mathrm{W}$; ROM 93740 , 1, $57.0 \mathrm{~mm}$ SL, Babahoyo Canton, Clara River at La Clara around bridge and downstream, $01^{\circ} 40^{\prime} 29.82^{\prime \prime} \mathrm{S}$, $79^{\circ} 23^{\prime} 14.22^{\prime \prime} \mathrm{W}$. Bolivar Province: ROM 93747, 4, 52.5-58.6 mm SL, Chilanes Canton, Tambo River at uppermost bridge in San Jose del Tambo, 01 ${ }^{\circ} 57^{\prime} 29.58^{\prime \prime} \mathrm{S}, 7^{\circ} 13^{\prime} 02.10^{\prime \prime} \mathrm{W}$. Cañar Province: ROM 93769, 3, 27.5-46.8 mm SL, Cañar Canton, Cutahay River at bridge crossing, $02^{\circ} 18^{\prime} 12.42^{\prime \prime} \mathrm{S}$, 79¹0'23.94"W; ROM 93783, 2, 56.7-75.4 mm SL, Canar Province, Canar Canton, Alberjita River at Primero de Mayo bridge, $02^{\circ} 18^{\prime} 35.70^{\prime \prime} \mathrm{S}, 79^{\circ} 11^{\prime} 04.62^{\prime \prime} \mathrm{W}$. 


\section{ACKNOWLEDGMENTS}

We gratefully acknowledge the collection managers and museum workers M. Burridge (ROM), E. Holm (ROM), D. Stacey (ROM), D. Werneke (AUM), D. Wylie (INHS), and M. Zur (ROM) for generously sharing information and processing specimen loans; A. Williston and K. Hartel (MCZ) for generating and sharing CT data of the Cordylancistrus torbesensis paratype MCZ 36170; ROM curator H. López Fernández for providing facilities and research space; and the expedition participants J. Arbour (U of Toronto), D. Brooks (MICA), A. Jackson (TAMU), F. Hauser (U of Toronto), H. López Fernández (ROM), N. Lovejoy (U of Toronto), K. Roach (TAMU), V. Roman (UCE), and D. Taphorn (ROM) for helping to collect specimens. Funding for this research came from NSF OISE-1064578 (International Research Fellowship) to NKL, and the Coypu Foundation. Additional funding for fieldwork and research came from the Life in Crisis: Schad Gallery of Biodiversity, Museum Volunteers research grants $(2009,2010)$ from the Royal Ontario Museum to H. López Fernández. Salary support for NKL provided by NSF DEB-1257813 (the iXingu Project).

\section{LITERATURE CITED}

Antonelli, A., J. A. A. Nylander, C. Persson, and I. Sanmartín. 2009. Tracing the impact of the Andean uplift on Neotropical plant evolution. Proceedings of the National Academy of Sciences of the United States of America 106:9749-9754.

Armbruster, J. W. 2003. Peckoltia sabaji, a new species from the Guyana Shield (Siluriformes: Loricariidae). Zootaxa 344:1-12.

Armbruster, J. W. 2004. Phylogenetic relationships of the suckermouth armoured catfishes (Loricariidae) with emphasis on the Hypostominae and the Ancistrinae. Zoological Journal of the Linnean Society 141:1-80.

Armbruster, J. W. 2008. The genus Peckoltia with the description of two new species and a reanalysis of the phylogeny of the genera of the Hypostominae (Siluriformes: Loricariidae). Zootaxa 1822:1-76.

Brooks, D. R. 1992. Origins, diversification, and historical structure of the helminth fauna inhabiting neotropical freshwater stingrays (Potamotrygonidae). Journal of Parasitology 78:588-595.

Burgess, W. E., and L. Finley. 1996. An Atlas of Freshwater and Marine Catfishes: Update. Tropical Fish Hobbyist October 1996:163-174.

Gregory-Wodzicki, K. M. 2000. Uplift history of the Central and Northern Andes: a review. Geological Society of America Bulletin 112:1091-1105.

Isbrücker, I. J. H. 1980. Classification and catalogue of the mailed Loricariidae (Pisces, Siluriformes). Verslagen en
Technische Gegevens, Instituut voor Taxonomische Zoölogie, Universiteit van Amsterdam 22:1-181.

Isbrücker, I. J. H. 2001. Nomenklator der Gattungen und Arten der Harnischwelse, Familie Loricariidae Rafinesque, 1815 (Teleostei, Ostariophysi). Datz Harnischwelse 2:25-32.

Lovejoy, N. R. 1996. Systematics of myliobatoid elasmobranchs: with emphasis on the phylogeny and historical biogeography of neotropical freshwater stingrays (Potamotrygonidae: Rajiformes). Zoological Journal of the Linnean Society 117:207-257.

Lujan, N. K., and J. W. Armbruster. 2011. Two new genera and species of Ancistrini (Siluriformes: Loricariidae) from the western Guiana Shield. Copeia 2011:216-225.

Lujan, N. K., J. W. Armbruster, N. R. Lovejoy, and H. López-Fernández. 2015. Multilocus molecular phylogeny of the suckermouth armored catfishes (Siluriformes: Loricariidae) with a focus on subfamily Hypostominae. Molecular Phylogenetics and Evolution 82:269-288.

Lujan, N. K., V. Meza-Vargas, V. Astudillo-Clavijo, R. Barriga-Salazar, and $\mathbf{H}$. López-Fernández. In press. A multilocus molecular phylogeny for Chaetostoma clade genera and species with a review of Chaetostoma (Siluriformes: Loricariidae) from the central Andes. Copeia.

Nuttall, C. P. 1990. A review of the Tertiary non-marine molluscan faunas of the Pebasian and other inland basins of north-western South America. Bulletin of the British Museum of Natural History (Geology) 45:165-371.

Sabaj Pérez, M. H. (Ed.). 2014, Standard symbolic codes for institutional resource collections in herpetology and ichthyology: an Online Reference. Version 5.0 (22 September 2014). Electronically accessible at http://www. asih.org/, American Society of Ichthyologists and Herpetologists, Washington, D.C.

Salcedo, N. J. 2013. Description of Loraxichthys lexa, new genus and species (Siluriformes: Loricariidae) from the Río Huallaga Basin, central Peru, with notes on the morphology of the enigmatic Lipopterichthys carrioni Norman, 1935. Zootaxa 3640:557-571.

Schaefer, S. A. 1997. The neotropical cascudinhos: systematics and biogeography of the Otocinclus catfishes (Siluriformes: Loricariidae). Proceedings of the Academy of Natural Sciences of Philadelphia 148:1-120.

Tan, M., and J. W. Armbruster. 2012. Cordylancistrus santarosensis (Siluriformes: Loricariidae), a new species with unique snout deplatation from the Río Santa Rosa, Ecuador. Zootaxa 3243:52-58.

Taylor, D. W. 1991. Paleobiogeographic relationships of Andean angiosperms of Cretaceous to Pliocene age. Palaeogeography, Palaeoclimatology, Palaeoecology 88: 69-84. 